THURSDAY, JULY 27, 1916.

\section{THE NATIONAL AWAKENING.}

$W^{H E N}$ the events of the early days of the South African war made men reflect upon the consequences of a conflict with a strong European Power, the nation was partly awakened from its sleep in the Garden of Ease. There were demands for the reorganisation of our forces for peace and war, and an incipient feeling prevailed that the plan of depending upon rule-of-thumb methods and knowledge acquired from endless mistakes-many of them painful-was not completely satisfactory. Over-prosperity was responsible for the lethargy into which we had fallen, and we began to learn in the school of adversity that modern struggles require strenuous preparation for success. With the end of the war, however, the stimulus subsided, and the nation again closed its eyes to the marvellous progress which other countries were making.

We have now been at war for nearly two years with the chief of these countries; and the consequent dislocation of trade and commerce has forced attention upon the ramifications of its influence throughout our Empire. It is realised now more than ever before that the development of our natural resources, and the profitable employment of our discoveries, have been left largely to the initiative of an alien people, and that there must be an Imperial Renaissance if we are to be independent of such enterprise in the future. We entered into the war in defence of international right against an aggressive military Power: we have to see that, when success has been achieved by our arms, the nation is fully prepared for the economic struggle to follow.

The recent activities of many national interests show that the need for a new Imperial policy is widely understood. Political parties have united to present an undivided front to the enemy; and whatever opposition exists to them has for its object the effective prosecution of the war and the promotion of industrial progress afterwards. We hope that the electorate will never again be deluded by the platitudes of the party politician of the pre-war era, and that the line of cleavage will be between obscurantism and progressive development. Commerce, industry, and education have ranged themselves with science to fight inactivity and inefficiency. Educational associations are endeavouring to produce reformed curricula and connecting links between school and university; trade associations and chambers of commerce No. 2439, VOL. 97] are asking for the creation of departments of State which will promote the development of industry and research and co-ordinate their efforts; engineers, chemical manufacturers, and other productive bodies have organised themselves for the advancement of their particular interests; and scientific societies have formed a joint committee to deal with matters of national importance. All these bodies are separate organisations, though their aims are the same. It is obviously desirable that, while retaining their individual characteristics, they should, to give them political strength, come together in a single body like the British Science Guild, which represents the interests of education, commerce, and industry, as well as of science.

Without a unifying policy there is little possibility that a sufficient body of opinion will be created to carry into effect the reforms which are being advocated. A series of articles on "The Elements of Reconstruction," which began in the Times of July $\mathrm{x} 7$, traces the outlines of an economic principle by which "those who are attacking the problem of the industrial reorganisation of the Empire and those who are working for educational reconstruction" may be made to join hands. The State has already assumed full powers of reorganisation towards the scientific foundations of industries concerned with the provision of munitions of war: it should be induced to carry on the same policy after the war, and thus enable the nation to meet the competition of advancing rivals. In business the dominating influence is individual interest, and it will not be necessary to urge the advantages of education and science when the community as a whole really believes that they can be made creators of wealth. These agents must be brought into close connection with economic life if they are to have a decisive voice in national affairs. This does not mean that teachers and men of science should necessarily seek seats in Parliament, but they should associate themselves with any organisation which endeavours to secure supporters for measures designed to increase national efficiency by means of educational and scientific work.

The action of the State when it comes in contact with business must be determined by economic values and represent the action of the community as a whole in the conduct of modern business. The only way in which the community can advance as a whole is by an increase of the total production or an improvement in the quality of what can be distributed. To secure either of these things knowledge must be kept progressive; and, if wisdom is to control the State, provision 
must be made for its development to the utmost. It is only by the introduction of these principles into the field of practical politics that the resources of the Empire can be fully developed, and we shall be able to hold our own against the competition of other countries, or maintain that supremacy which was obtained under entirely different conditions by rule-of-thumb methods and speculation.

Mr. Henderson, the President of the Board of Education, referred to the changing conditions, and the need for reform, in his speech in presenting the Education Estimates to the House of Commons on July 18 . In the course of his remarks he said:

The war is assisting in the creation of a greater body of public opinion in favour of a more liberal expenditure on education; and the essential importance of a comprehensive and efficient system of education on the progressive development of national life and the solidifying of the Empire is going to be more universally recognised. This principle must be encouraged and fostered, and on no account should the nation, in consequence of its expenditure on the war, be detained from bringing it into action.

The Government has decided to appoint committees to reorganise our whole system of education, and one of these committees will be concerned with the position of science. British educational endeavour has too of ten proved unproductive because of its haphazard character and its control by men out of touch with modern needs. A classical education at one of the fashionable public schools, followed by something very similar at an ancient university, accompanied probably by the pursuit of some branch of athletics and almost certainly by a continuous neglect of all branches of science, is the typical training of our statesmen and administrators. It is impossible for these men to know what scientific teaching means to the nation, or to understand the real difference between it and purely literary studies. Book-learning may be ornamental to the individual, but it is not of much practical value to a progressive community and is a danger when it prevents attention to scientific things. None of us wish the training of character to be disregarded in education, nor do we desire to depreciate the influence of literature, art, philosophy, and religion. But we have to safeguard our existence both in peace and war, and scientific knowledge is necessary to ensure this aim. The Empire is awake to the need for a policy which will correlate education, science, and industrialism for the benefit of all classes : if our statesmen do not respond to the call to action we hope that a new party of reform will arise to drive them into the wilderness.

No. 2439, VOL. 97]

\section{SCIENCE FOR LIFE.}

Discovery; or, The Spirit and Service of Science. By R. A. Gregory. Pp. $x+340$. (London: Macmillan and Co., Ltd., I9I6.) Price 5 s. net.

THIS book is the realisation of a long-cherished 1 project, "une pensée de la jeunesse exécutée par l'âge mûr," its ambition being to make clear what science-and natural science in particularaims at, what its human values are, and what spirit characterises the discoverer. We think that Mr. Gregory has done notable service in submitting his apologia at the present time, when the disposition to turn with expectation to science is probably more widespread than ever in the past, and we would congratulate him on the success with which he has stated his case. For while he hides no convictions, he has written temperately and good-humouredly, with such wealth of concrete and personal illustration that there is no hint of sermonising to offend. Perhaps the only passage in the book which betrays a trace of impatience-and we are not surprised-is one in which the author speaks his mind in regard to politicians. But it is all "good hunting," and the politicians will not wince at worse.

We admire greatly the restrained enthusiasm with which Mr. Gregory writes of the advancement of natural knowledge and of the great masters who have contributed to this, and the carefulness with which he gives chapter and verse from the history of science, so that even a prejudiced reader cannot but be impressed. Contributing greatly to the pleasant temper of the book is the author's evident sympathy with humanistic as well as scientific studies, and his clear recognition that if an antithesis is made there is something wrong either with the science or the humanism. It is ours to warm both hands at the fire of life.

Mr. Gregory is quite clear that scientific work is not confined to any particular body of facts or to any number of laboratories. As Clifford said, "there are no scientific subjects. The subject of science is the human universe--that is to say, everything that is, or has been, or may be related to man." "The work of science," Ruskin said, " is to substitute facts for appearances and demonstrations for impressions." These quotations are taken from a very interesting series (not of uniform value, we must confess), which occur as a sort of intellectual hors d'ouvre at the beginning of each of the twelve chapters.

"La République n'a pas besoin de savants," coldly remarked the president of the tribunal of French Revolutionists which condemned Lavoisier to death in I793, and a "crime against the whole intellectual world" was perpetrated. In such measure as science is wilfully neglected and discoverers are starved or smothered in toil, civilisation remains impenitent, and it is part of the merit of this book that it presses the charge home. The fine chapter on "The Conquest of Disease" illustrates one side of the debt that humanity owes to science, and not less eloquent chapters on 